Luckily it was now nearly four o clock, and when I was acting I always dined at four, so I asked the two men to stay to dinner. They both gloomily accepted.

We sat down to table. The maid handed some dish to Mr Shaw.

'No, thank you,' he said. 'I never eat meat.'

This seemed absolutely the last straw, and I don't think I completely recovered until he rose to go.

Before leaving he turned and fired a parting shot.

'I didn't have you in my mind for the part, Mr Terriss,' he said coldly. 'I wanted Miss Millward, and I hope that some day she will play in one of my pieces.'

\title{
You Never Can Tell
}

\section{EVA MOORE}

From Eva Moore, Exits and Entrances (London: Chapman \& Hall, 1923) p. 108. Eva Moore (1870-1955) played Dolly in rehearsals for an eventually abandoned production of You Never Can Tell in the spring of 1897 - described humorously and anonymously by Shaw in chapter 16 of Cyril Maude, The Haymarket Theatre (London: Grant Richards, 1903). The first public performances waited until May 1900, when Yorke Stephens and James Welch presented six matinées at the Strand Theatre.

GEORGE BERNARD SHAW: I once rehearsed for a play of his at the Haymarket Theatre. I remember he used to sit at rehearsals with his back to the footlights, tilting his chair so far on its hind legs that it was only by the intervention of heaven that he did not fall into the orchestra. There he sat, always wearing kid gloves, firing off short, terse comments on the acting, and rousing everybody's ire to such an extent that the fat was in the fire, and finally the production was abandoned, after five weeks' rehearsal!

\section{John Bull's Other Island}

From C. K. Shorter, 'George Bernard Shaw - a Conversation: Concerning Mr 